\title{
Mechanistic Biomarkers in Toxicology
}

\section{Toksikolojide Mekanistik Biyobelirteçler}

\author{
(D) Sonia SANAJOU*, (D) Gönül ŞAHIN \\ Faculty of Pharmacy, Eastern Mediterranean University, 99628, Famagusta, North Cyprus, Via Mersin 10, Turkey
}

\begin{abstract}
Biomarkers are important parameters that are reliable, applicable, reproducible, and generally inexpensive. All biomarkers have a significant role in human health, especially mechanistic biomarkers, which are the most important for the prevention of toxic effects and diseases. They demonstrate the possibility of diagnosis, prognosis, recurrence, and spread of disease. Furthermore, they show the exposure levels to numerous chemical, biological, and physical agents. To date, the development and application of biomarkers require the knowledge of mechanisms underlying their production. Therefore, the present study focused on the possible mechanistic biomarkers.
\end{abstract}

Key words: Mechanistic, biomarker, toxicology

öz

Biyobelirteçler önemli, güvenilir, uygulanabilir, tekrarlanabilir ve genelikle maliyeti uygun parametrelerdir. Biyobelirteçlerin insan sağlığı açısından önemli rolü olmakla birlikte özellikle mekanistik biyobelirteçlerin toksik etki ve hastalıklardan korunmada önemi büyüktür. Biyobelirteçler hastalıkların tanısını, gidişatını, tekrarlama ve yayılma olasılığını, tedavinin etkinliğini gösterebilir. İlave olarak birçok kimyasal, biyolojik ve fiziksel ajanlara maruz kalma düzeyini gösterir. Bugün biyobelirteç geliștirilmesi ve uygulanması, bunların oluşumunun altında yatan mekanizma bilgilerini gerektirir. Bu nedenle bu yazıda olası mekanistik biyobelirteçler üzerinde yoğunlaşılmıştır.

Anahtar kelimeler: Mekanistik, biyobelirteç, toksikoloji

\section{INTRODUCTION}

The National Institutes of Health defines a biomarker as "a characteristic that is objectively measured and evaluated as an indicator of normal biological processes or pharmacological responses to a therapeutic agent"1,2 Parameters, such as glomerular filtration rate or recorded blood pressure at different time intervals, are examples of biomarkers. Generations of epidemiologists, physicians, and scientists have used various biomarkers to study human diseases. Biomarkers have been used in the management and diagnosis of cardiovascular diseases, infections, genetic disorders, cancer, and others. ${ }^{3}$ The time course of injury and underlying molecular mechanisms are reflected by the measuremment of biomarkers. Accurate diagnosis, prognosis, and treatment regime can be applied to a patient by analyzing different biomarkers. ${ }^{2}$ Periodic surveillance of biomarkers also serves as a tool to determine whether a treatment protocol or daily dietary habits are improving the patient's condition. ${ }^{2}$ The periodic follow-up of biomarkers will provide the health care personnel with important information about the efficacy or toxicity of the treatment regime and act as a border for clinical trials, with the final goal of treating the patients with safe and effective medical therapies. ${ }^{2}$

Biomarkers are generally classified as biomarkers of (i) exposure, (ii) effect, and (iii) susceptibility. 2,4 Exposure biomarkers are considered early markers, which result from the interaction between a chemical agent and a target molecule. ${ }^{4}$ Therefore, these biomarkers are essential and valuable in collaboration with biomarkers of early disease detection to develop personalized medical treatment strategies. ${ }^{2}$ The biomarkers of effect are considered late markers. They are used to measure the burden of injury or damage caused by different agents on the target organ. These biomarkers are also employed to objectively and accurately measure the overall health status of patients, usually after being exposed to an agent or disease. ${ }^{4}$ Susceptibility biomarkers are used as a guide to inherent or gained ability of the body to respond 
to difficulties. These markers are the result of exposure to diseases or chemicals. ${ }^{4,5}$

Biomarker development requires detailed and considerable knowledge. Studies about the pathogenesis of diseases, molecular changes, and alterations in biochemical pathways underlying toxic effects should be conducted. Such mechanistic information causes the formation of mechanistic biomarkers. Mechanistic biomarkers cover exposure, effect, and susceptibility biomarkers and lead to the generation of new ones. ${ }^{6,7}$ Therefore, they have the highest potential for assisting with clinical decision making. The best example of a mechanistic marker is a genetic trait index, which is commonly used for the diagnosis of certain diseases. Mechanistic biomarkers provide information regarding patient prognosis and the probability of response to various treatment options; however, it is not used for follow-up of progression nor response to an applied medical therapy. ${ }^{6,8}$ Numerous biochemical processes, such as oxidative stress, alterations in biotransformation, alteration in protective and repair systems, and organelle damage, are the mechanistic information that lead to detectable biomarkers.

\section{Oxidative stress biomarkers}

In 1985, Helmust Sies defined "oxidative stress as a disturbance in the prooxidant-antioxidant balance in favor of the former". Oxidants are mostly produced by cellular metabolism. The antioxidant system of the body quickly eliminates small amounts of oxidants, but in certain cases, they cause remarkably profound damage to macromolecules (proteins, lipids, DNA, and carbohydrates) (Figure 1). Reactive oxygen species (ROS), such as hydrogen peroxide, superoxide radicals, and hydroxyl radicals, are common by-products of metabolic activities. ${ }^{2,10} \mathrm{ROS}$ are synthesized during mitochondrial respiration, inflammation, immune system activity, and other processes. ${ }^{2,11-13}$ The increase in oxidative stress level increases the production of ROS through Fenton reaction (reduction of iron by superoxide).,11,14 Excess amounts of ROS interfere with the physiological activity of mitochondria and result in adenosine triphosphate (ATP) depletion. An increase in oxidative stress levels has also been associated with numerous diseases or toxicities. A substantial amount of evidence reveals the association between oxidative stress and different diseases, such as cancer, diabetes, infections, cardiovascular and neurodegenerative diseases, and the aging process (Figure 2). 2,12,15

Markers of oxidative stress are used to evaluate the nature and effect of ROS. The measurement of ROS may be a useful marker, but such method is unstable; their detection requires invasive methods, and the results may lack specificity. Thus, scientists measure the by-products of the reaction of ROS with other biomolecules that are more stable. Surrogate markers include nitrite and nitrate levels, products of lipid peroxidation, and levels of oxidized proteins." Figure 1 shows the effect of ROS on macromolecules and several end products.

Lipid peroxidation is a cascade of reactions due to ROS attack on lipids in the cell membrane, and it has been implicated in various diseases, such as hypertension, Alzheimer's disease, cancers, and other disorders. ${ }^{16-19}$ The burden of lipid peroxidation

can be measured by analyzing thiobarbituric acid, N-epsilonhexanoyl-lysine, malondialdehyde, 4-hydroxy-nominal, and F2-isoprostane 15(S)-8-iso-prostaglandin F2 $\alpha$, which are byproducts of lipid peroxidation. . $^{170}$

\section{Antioxidants}

The human body is equipped with different antioxidant systems that serve as a counterbalance to the effect of oxidants. The antioxidant defense involves several strategies, namely, enzymatic and non-enzymatic mechanisms. Enzymatic mechanisms, such as superoxide dismutase (SOD), and nonenzymatic defense systems, protect cells against free radicals and ROS. Antioxidants, including alpha-tocopherol, scavenge oxidants (which damage cell membranes and cause lipid peroxidation) or ascorbate-trap ROS. ${ }^{15}$

Glutathione (GSH) is a three-peptide molecule that contains cysteine, glycine, and glutamate, and it is the most critical molecule of the antioxidant system. GSH plays a significant role in the detoxification of aggressive electrophilic molecules, such as radicals, epoxides, and halides, by conjugation reactions. GSH is the major thiol in the body and a perfect reductant molecule that prevents oxidative damage. ${ }^{21}$ The ratio of reducedto-oxidized GSH indicates the redox balance of the cell. This redox balance is an indicator of the overall health of cells. ${ }^{22}$ Dysregulations in GSH synthesis and its concentration are considered important biomarkers in the diagnosis of diseases, such as human immunodeficiency virus, cancer, inflammation, tuberculosis, Alzheimer's disease, and numerous others. ${ }^{23-25}$ The evaluation of the GSH pathway will reflect the status of the antioxidant system, which may elucidate various underlying pathology etiologies. Among the enzymes that participate in the antioxidant system, GSH peroxidases (GSH-Pxs) consist of four enzymes (Table 1), ${ }^{26,27}$ all of which contain selenium. These GSH-Pxs are hydrogen and lipid peroxide scavengers. Hydrogen peroxide is produced during cell metabolic processes, and its amount increases under oxidative stress. ${ }^{15}$

\section{Table 1. Different GPX enzymes}

The enzyme Location

Glutathione peroxidases I, neutralizes hydrogen peroxide and protects

Glutathione peroxidases II; this isoenzyme level increases in different cancers such as prostate, hepatocellular, and breast cancers 29,30

Cell cytosol, especially in the gastrointestinal tract

Glutathione peroxidases III; It is a glycoprotein 29,30

Plasma

Glutathione peroxidases IV; It is activated

in case of free radical damage, serum cholesterol, and lipoproteins $^{29}$

GPX: Glutathione peroxidase

Another essential enzyme in the antioxidant system is SOD, which eliminates superoxide radicals. ${ }^{31}$ SOD has three 


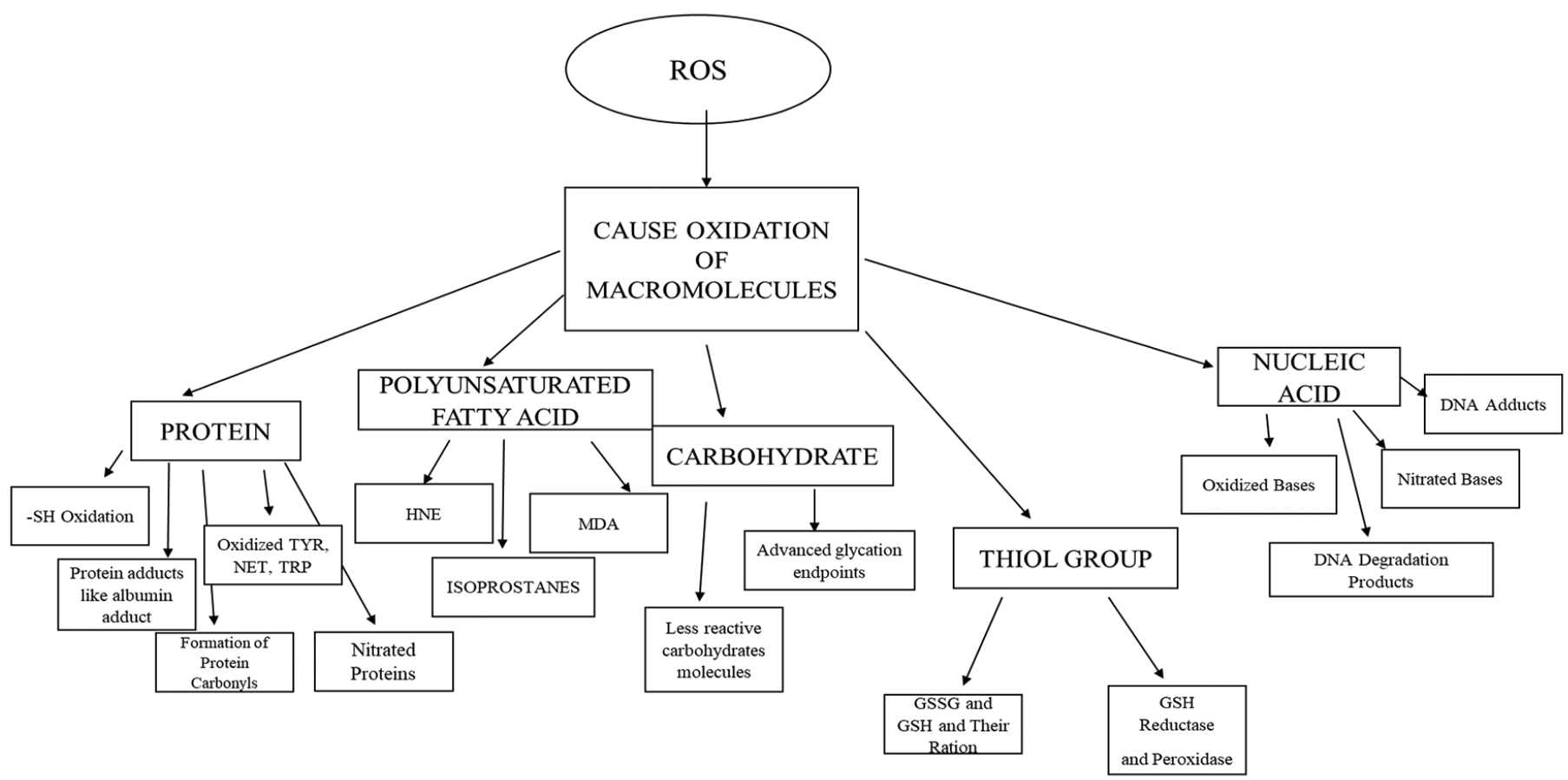

Figure 1. ROS cause the oxidation of macromolecules. As a result of this oxidation, the end products of the oxidation process have been mentioned. These end products are used as biomarkers to detect the presence of oxidative damages (drawn by authors)

ROS: Reactive oxygen species

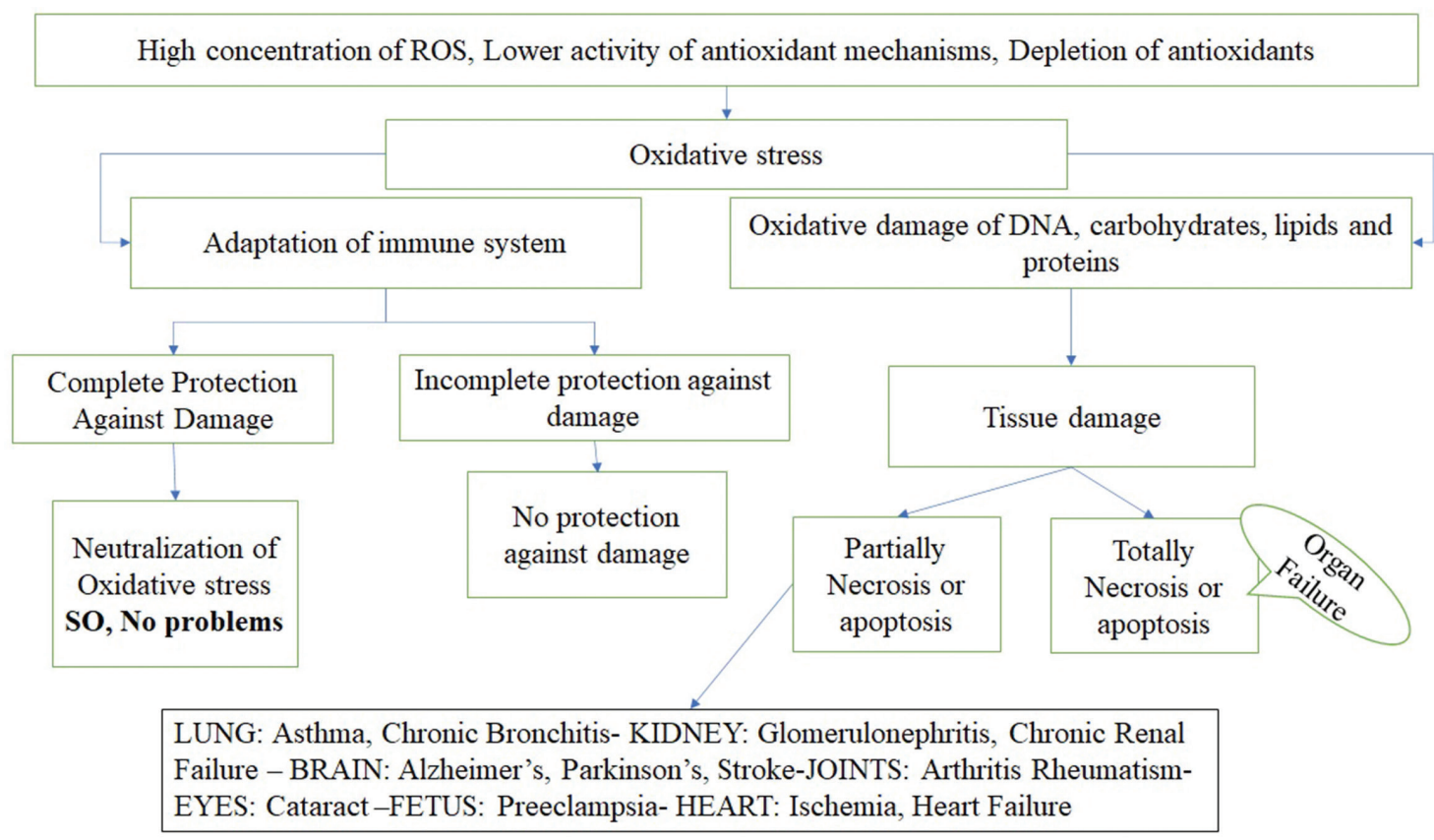

Figure 2. Oxidative stress in the general pathogenesis of diseases (drawn by authors)

metalloenzyme forms, namely, cytoplasmic Cu/Zn-SOD, mitochondrial Mn-SOD, and extracellular EC-SOD, all of which require cofactors ( $\mathrm{Cu}$ or $\mathrm{Mn}$ ) for their activity. ${ }^{32,33}$ Hydrogen peroxide formation results from the neutralization of superoxide. Catalase and GSH-Px enzymes then catalyze this $\mathrm{H}_{2} \mathrm{O}_{2}$. Given that all these enzymes depend on each other, fluctuations in their levels will affect the overall antioxidant system. ${ }^{15,34}$

\section{Biomarkers related to biotransformation}

Biotransformation is the process of enzymatic transformation of xenobiotics to excretable metabolites. However, in certain cases, the metabolites may be toxic and reactive electrophiles. These toxic metabolites lead to cell damage or cell death. The measurement of active metabolites (such as morphine as the active metabolite of codeine biotransformation), determining 
the effect of reactive metabolites on macromolecules and the analysis of end products (such as of mercapturic acid or hippuric acid in urine samples), and measurement of enzyme activity, which is responsible for xenobiotics metabolism, are several of the biomarkers related to biotransformation. ${ }^{2}$

The effect of xenobiotics or toxins is dependent on their metabolism, which is controlled by the action of enzymes. Any modification in the activity of these enzymes results in a change in the fate of xenobiotics. Metabolization can be altered by enzyme induction or inhibition. Enzyme induction or inhibition has been studied as a biomarker for the measurement of responses to environmental pollutants, exposure to various drugs, or drug interactions. ${ }^{35}$ Chronic alcohol usage results in the induction of the 2E1 enzyme. The induction of this enzyme will alter the fate of specific drugs that are metabolized by it. $^{36}$ Organophosphate pesticides reversibly or irreversibly bind to and inhibit cholinesterase. This inhibition prevents neurotransmitter (acetylcholine) degradation. ${ }^{37}$ Quinidine is a potent CYP2D6 inhibitor. ${ }^{38}$ In polypharmacy, the inhibition or induction of enzymes is very important. The first or second drug interferes with the other drug's biotransformation, and the outcome is either the toxicity or absence of a therapeutic activity. ${ }^{39}$

Differences in genetic traits that cause differences in the expression and activity of enzymes are the primary cause of susceptibility to various diseases. The mutations and alterations in genes can be detected in 1\% of populations, a phenomenon called genetic polymorphism. Polymorphisms in phase I and Il biotransformation enzymes or DNA repair enzymes can be biomarkers. The polymorphisms of GSH S-transferase, $\mathrm{N}$-acetyl transferase, and CYP1A2, 2A6, 2D6, and 2E1 have been studied ${ }^{2}$ in various conditions; as an example, the polymorphism of CYP2C9 causes the patient to need less doses of warfarin, which will increase the susceptibiltiy of the patient to increased risk of bleeding and in the case of CYP2C19, the increased risk of anticonvulsant side effects. ${ }^{40}$ People who are CYP2D6 polymorphic need high doses of fluoxetine to show the same plasma levels as those with normal CYP2D6. ${ }^{41}$

Furthermore, protein expression and function can be altered as a result of molecular response to signals, post-translational modifications, and other factors..$^{40}$ Additionally, the measurement of the parent-compound-to-metabolite (metabolite ratio) ratio is considered an applicable and practicable biomarker. The measurment of metabolic ratio is a valuable indicator of the metabolism rate. If the ratio is high, the patient is a poor metabolizer, and vice versa. Codeine is converted to morphine by CYP2D6 to show its analgesic effect. However, in poor metabolizers, codeine is a poor analgesic. ${ }^{42}$

\section{$D N A$}

DNA damage is a sign of several disorders, such as colon cancer, chronic renal damage, and aging-related problems. ${ }^{43,44}$

DNA damage can be caused by endogenous agents, such as various metabolic by-products, and environmental factors, such as ultraviolet and ionizing radiation. ${ }^{45,46}$ ROS also cause DNA damage. The degree of DNA damage can be used as a biomarker to assess the oxidative stress in various conditions, such as pancreatic and mammary cancers and the damage from ionizing radiation that is used for radiotherapy of cancer patients. ${ }^{46}$

Certain compounds undergo bioactivation reactions that result in the production of potentially carcinogenic metabolites. These metabolites are carcinogenic because they react with the DNA and form DNA adducts. The metabolism of benzo (alpha) pyrene results in the formation of a cation radical, which forms DNA adducts, during exposure to tobacco smoke or coal. ${ }^{47}$ In addition, reactive oxygen and nitrogen species can directly interact with DNA. ${ }^{48}$ This interaction causes the oxidation of DNA and produces DNA adducts. The most important of these oxidative DNA adducts are 8-hydroxydeoxyguanosine (8-OHdG), thymine glycol, hydroxymethyl uracil, 8-hydroxydeoxyadenine, and formylamidopyrimidine. The measurement of oxidized bases from urine samples is a good indicator of the oxidative damage of nuclear DNA, which occurs during carcinogenesis, and an important prognostic factor for certain cancers. ${ }^{48}$

Damage to mitochondrial DNA is mainly caused by oxidative stress damage. The DNA repair systems are incomplete in the mitochondria, which increases the susceptibility and mitochondrial dysfunction. Therefore, this damage directly interferes with oxidative phosphorylation and results in the induction of apoptosis and cell death. The increased levels of 8-OHdG in biological samples can be a surrogate marker for mitochondrial DNA damage. ${ }^{48}$

DNA repair systems have an important role in repairing DNA damage at first sight. If the DNA repair systems are defective or overwhelmed, the risk of cancer and various diseases related to aging increases. ${ }^{48}$

Cofactors: Nicotinamide (NAM) adenine dinucleotide (NAD)+ and NAM adenine dinucleotide phosphate (NADP)+

Cofactors mediate a wide range of biological reactions. NAD [reduced form: NAD(H)], NADP [reduced form: NADP $(H)$ ], and ATP are important mechanistic biomarkers. NAD+ was first discovered in 1906. ${ }^{49-52} \mathrm{NAD}^{+}$and NADH play an important role in various metabolic processes, such as glycolysis, mitochondrial oxidative phosphorylation, oxidation of fatty acids, citric acid cycle, and other oxidation-reduction (redox) reactions. ${ }^{51-53}$ Its effects determine the circadian change..$^{50,51}$ Fluctuations in the $\mathrm{NAD}^{+}$level have a significant effect on cell function and metabolism. As shown in Figure $3, \mathrm{NAD}^{+}$, as a co-substrate for three important enzymatic activities [sirtuin, poly (ADPribose) polymerases (PARPs), and redox enzymes], has gained attention recently. CD 38/CD157 are ectoenzymes that consume mitochondrial $\mathrm{NAD}^{+}$and degrade it to cyclic ADP ribose and NAM. The CD38 activity increases with age, resulting in the increased $\mathrm{NAD}^{+}$consumption and depletion of $\mathrm{NAD}^{+}$reserves. CD38 is overexpressed in chronic inflammation and chronic lymphocytic leukemia, whereas mitochondrial NAD+ is depleted in these diseases. PARPs play a role in epigenetics, DNA repair, and chronic inflammation. An increase in the expression of PARPs results in $\mathrm{NAD}^{+}$consumption and reduction of the NAD+ pool. Sirtuin is an important factor that increases the life span 


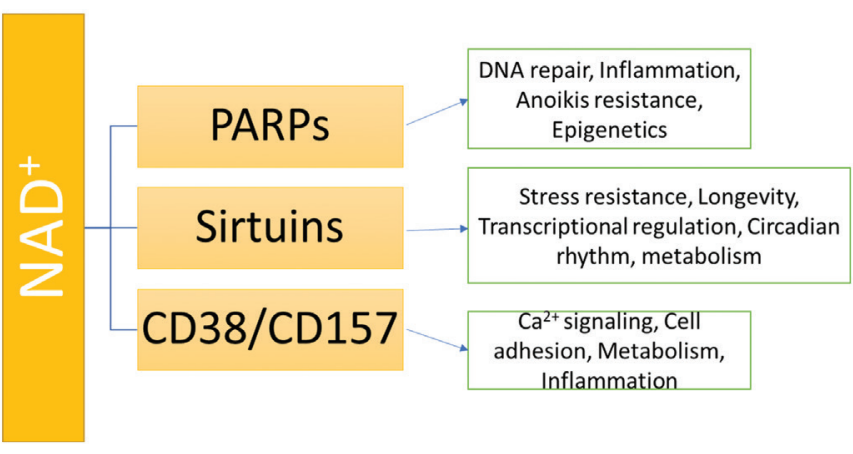

Figure 3. $\mathrm{NAD}^{+}$is a co-enzyme for the function of PARPs, sirtuins, and cyclic ADP-ribose synthases (CD38/CD157). Fluctuations in the NAD+ level affect the biological processes that are dependent on these enzymes ${ }^{51}$

NAD: Nicotinamide adenine dinucleotide, PARPs: Poly (ADP-ribose) polymerases, ADP: Adenine dinucleotide phosphate

of cells. Sirtuin pool decreases by aging along with the NAD+ pool. Thus, increasing the $\mathrm{NAD}^{+}$pool enhances the life cycle of cells. ${ }^{54}$ Sirtuin acts as a tumor suppressor by regulating transcription, programming the metabolic pathways of cells, and increasing cell resistance against oxidative stress. ${ }^{51,52}$ Through these enzymes, NAD+ affects the energy balance, stress response, and cellular homeostasis. ${ }^{50,54,55}$ Fluctuations in $\mathrm{NAD}^{+}$levels result in fluctuations in protein levels, which are dependent on $\mathrm{NAD}^{+}$, and thus, these proteins are significant in carcinogenesis. ${ }^{51}$

The increase in $\mathrm{NAD}^{+}$levels possibly reduces the risk of cancer, but this increase leads to the increased activity of PARP enzymes. PARPs promote the protection and repair of DNA, especially in cancer cells. PARPs cause the overexpression of inflammatory genes, which are responsible for the increased incidence of hormone-dependent tumors. ${ }^{51}$ Sirtuin is sensitive to the fluctuation in $\mathrm{NAD}^{+}$levels. Different sirtuin isoforms act as tumor suppressors by altering transcription and rescheduling the cell metabolic activity. ${ }^{51}$

Aging is an essential factor in decreasing the NAD+ synthesis. Aging means implies the susceptibility to chronic inflammation, circadian rhythm changes, and fluctuations in microRNA gene expression. All the factors mentioned above decrease the activity of NAM phosphoribosyltransferase (Nampt), which is an important enzyme in $\mathrm{NAD}^{+}$synthesis. Nampt is a ratelimiting enzyme in the $\mathrm{NAD}^{+}$salvage biosynthesis pathway from NAM. The decrease in Nampt activity results in the reduced synthesis of $\mathrm{NAD}^{+}$, increased $\mathrm{NAD}^{+}$degradation, and increased risk of age-related diseases. ${ }^{50}$

$\mathrm{NADP}^{+}$is formed by the addition of phosphate to $\mathrm{NAD}^{+}$. NADP ${ }^{+}$ and NADPH are critical cofactors, fighting against oxidative stress and playing a role in the synthesis of nucleic acids, fatty acids, and cholesterol. ${ }^{53-55}$

Thus, these redox couples act as a substrate for the majority of enzymes. They play an active part in cellular redox homeostasis. The deficiency in any of them disrupts this homeostasis, which results in oxidative stress, disease onset, and energy impairment.
Polyamines: Ornithine decarboxylase (ODC)

Polyamines are small, cationic amines derived from amino acids. They are required for healthy cell growth; however, they are also involved in cancer cell proliferation., ${ }^{1.56-59}$ Putrescine, spermidine, and spermine are the main polyamines in eukaryotes and prokaryotes.56,58 Dietary or endogenous polyamines produced by the gut microbiota and those that are synthesized in the cytoplasm are the chief sources for all cells and tissues. ${ }^{57,60}$ Given their significance in cell function, their levels are strictly regulated by maintaining a balance between synthesis, degradation, and uptake. ODC plays a critical role in the biosynthesis of polyamines. Increased levels of ODC enzyme in blood has been reported in regenerating tissues and in cancer. ${ }^{56,57}$

Along with chemical cancer promoters, which result in ODC increase, several environmental and genetic factors, such ultraviolet light, can result in increased $O D C$ gene expression. ODC levels have been reported to increase in skin, lung, and prostate cancers. ${ }^{56,57,60-62}$

s-Adenosylmethionine, which forms acetylated polyamines, is another enzyme in polyamine synthesis. Both the parent polyamines and acetylated derivatives (e.g., $\mathrm{N}_{1}$-acetyl spermidine, $\mathrm{N}_{8}$-acetylspermidine, $\mathrm{N}_{1}$-acetylspermine, and $\mathrm{N}_{1}$, $\mathrm{N}_{12}$-diacetylspermine) can be detected in urine and have been associated with cancer. ${ }^{60}$

Tumor cells with a high polyamine production show an increased synthesis of proteinases and cathepsins, which destroy the surrounding tissue. These cells also induce hypoxia, which results in the increased uptake of polyamines by cells and results in an increased proliferation rate. ${ }^{56,58}$

\section{Pteridine pathway: Folate and neopterin}

Pteridines are bicyclic nitrogenous ring system pyrazino-(2,3d)-pyrimidine derivatives that bear small substituents, such as neopterin and biopterin, and are called unconjugated pteridines. The derivatives with a large residues, such as folic acid and riboflavin, are called conjugated pteridines. ${ }^{63}$

Several crucial cellular mechanisms depend on folate as the source of 1-carbon in DNA synthesis and methylation of protein. Thus, folate plays a significant role in DNA synthesis. ${ }^{64-68}$ Dihydrofolate reductase and thymidylate synthase have been used as targets in chemotherapy, thus rendering conjugated pteridines as good candidate biomarkers. ${ }^{69}$ Folate deficiency leads to different disorders and diseases. ${ }^{70}$

Among folate derivatives, 5-methyltetrahydrofolate (5-methyl THF) is found in circulation, and it acts as a co-substrate in the conversion of homocysteine to methionine (Figure 4$)^{71}$. DNA mutations and strand breakage can also be the result of an increase in the replacement of uracil instead of thymidine. These events occur due to the decrease in 5,10-methyl THF.66,72 Moreover, the decreased levels of 5-methyl THF will lead to the reduced levels of s-adenosylmethionine, which will cause the activation of oncogenesis and increase DNA damage. ${ }^{73-75}$ For this reason, folate level can be a useful biomarker in predicting or diagnosing cancer. ${ }^{64,66}$ 


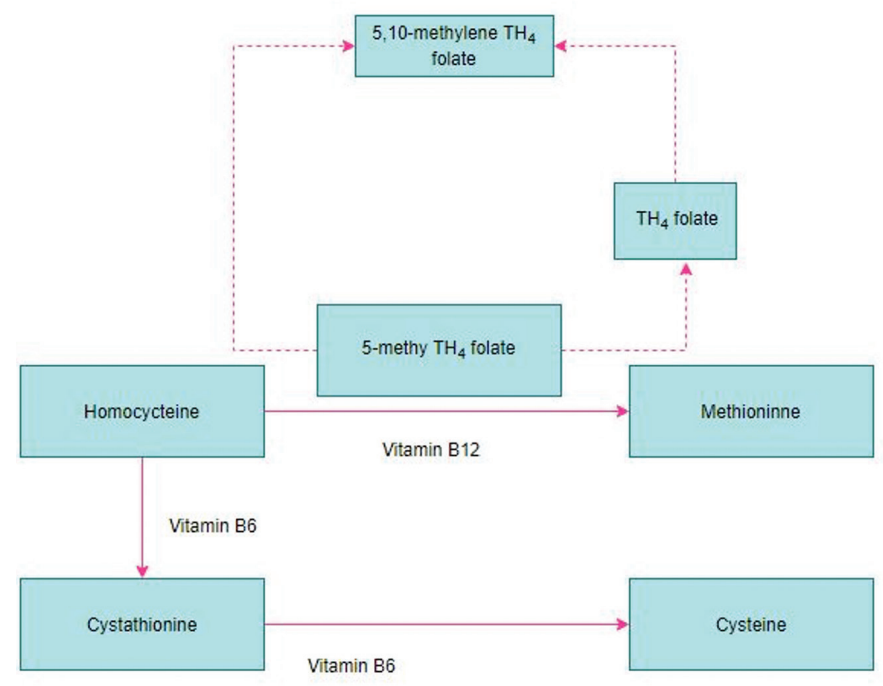

Figure 4. Conversion of homocysteine to methionine ${ }^{71}$

The relationship between folate and cancer is directly related to its dosage. Low doses of folate increase the risk of cancer. On the other hand, high doses of folate will reversely inhibit dihydrofolate reductase. Another risk factor for carcinogenesis is the circulation of the unreduced form of folate. Antifolate medications have been used widely in cancer therapy to inhibit single-carbon metabolism, which is necessary for cell proliferation in cancerous tissue. ${ }^{66,70}$ Other agents, such as chronic alcohol usage, ${ }^{76}$ antacids, ${ }^{77}$ and general anesthetics, ${ }^{78}$ cause depletion or alteration in folate levels.

Additionally, diseases, such as Crohn's disease, celiac disease, and several kind of cancers, result in folate depletion. The evaluation of folate levels is important in patients who have been on long-term diuretic therapies, including those using furosemide and amiloride. These medications increase the elimination of folate. ${ }^{70}$

The measurement of folate levels in the process of testing new therapeutic agents is considered a vital biomarker because of the essential role of folate in DNA biosynthesis and red blood cell synthesis. The depletion of folate levels increases the rate of cardiovascular and neuronal disorders. ${ }^{73}$

Unconjugated pteridines and their derivatives act as intermediates in metabolism, and their biological concentrations have shown changes in various disease processes. Unconjugated pteridines can be measured in the serum, cerebrospinal fluid, and urine. ${ }^{79}$ Neopterin, as an unconjugated pteridine, is one of the early biomarkers for cancer, systemic diseases, infectious and/or inflammatory diseases such as HIV, rheumatoid arthritis, Behçet disease, and acute myocardial infarction. Neopterin became popular among scientists because it is highly fluorescent, and it can be synthesized easily by gamma interferon-activated macrophages and monocytes. ${ }^{11,80,81}$ 7,8-dihydroneopterin, a form of neopterin produced by macrophages, acts as a radical scavenger and inhibits free radicals that are formed during lipid and protein oxidation. 7,8-dihydroneopterin is a hydroxyl, superoxide, and peroxyl scavenger. Surveillance of neopterin in body samples is a good indicator of the levels of free radicals in tissues and cells. ${ }^{82}$ The Austrian government has been using neopterin screening to test donated blood to ensure their safety. ${ }^{83}$ Neopterin screening can also be used to predict a patient's inflammatory status. ${ }^{84-86}$

\section{CONCLUSION}

In general, biomarkers are used to measure the response of biological systems. In the field of toxicology, biomarkers are practical tools to understand the mechanisms of toxicity. They are also useful in risk management and assessment. From the toxicological aspect, biomarkers play an important role in the prevention and reduction of harmful effects of different chemicals and agents. Mechanistic biomarkers have been used as a tool in diagnosis, treatment, and monitoring of the treatment course of different diseases, such as cancers, Alzheimer's disease, immunological disorders, and other pathologies.

In conclusion, reliable and applicable proper biomarkers that accord with ethical rules are beneficial for human health. Nevertheless, further research is still needed to define ideal biomarkers for different fields of life sciences.

Conflicts of interest: No conflict of interest was declared by the authors. The authors alone are responsible for the content and writing of this article.

\section{REFERENCES}

1. Biomarkers Definitions Working Group. Biomarkers and surrogate endpoints: preferred definitions and conceptual framework. Clin Pharmacol Ther. 2001;69:89-95.

2. Gupta RC. Biomarkers in Toxicology. Kentucky: Elsevier, Academic Press; 2014.

3. Mayeux R. Biomarkers: potential uses and limitations. NeuroRx. 2004;1:182-188.

4. Aitio A, Anderson D, Blain P, et al. Biomarkers and risk assessment: Concepts and principles. Environmental Health Criteria 155. 1993;3-82. Available from: https://wedocs.unep. org/bitstream/handle/20.500.11822/29540/EHC155BRA. pdf? sequence $=1$ \&isAllowed $=y$

5. Nordberg GF. Biomarkers of exposure, effects and susceptibility in humans and their application in studies of interactions among metals in China. Toxicol Lett. 2010;192:45-49.

6. Robinson WH, Lindstrom TM, Cheung RK, Sokolove J. Mechanistic biomarkers for clinical decision making in rheumatic diseases. Nat Rev Rheumatol. 2013;9:267-276.

7. McGill MR, Woolbright BL, Weemhoff JL, Jaeschke H. Mechanistic Biomarkers in Liver Diseases. 2017:623-635.

8. Gutteridge JM. Lipid peroxidation and antioxidants as biomarkers of tissue damage. Clin Chem. 1995;41(12 Pt 2):1819-1828.

9. Sies H. Oxidative Stress: Introductory Remarks. Pergamon press inc.; 1985.

10. Giustarini D, Dalle-Donne I, Tsikas D, Rossi R. Oxidative stress and human diseases: Origin, link, measurement, mechanisms, and biomarkers. Crit Rev Clin Lab Sci. 2009;46:241-281. 
11. Dalle-Donne I, Rossi R, Colombo R, Giustarini D, Milzani A. Biomarkers of oxidative damage in human disease. Clin Chem. 2006;52:601-623.

12. Marrocco I, Altieri F, Peluso I. Measurement and Clinical Significance of Biomarkers of Oxidative Stress in Humans. Oxid Med Cell Longev. 2017;2017:6501046.

13. Pizzino G, Irrera N, Cucinotta M, Pallio G, Mannino F, Arcoraci V, Squadrito F, Altavilla D, Bitto A. Oxidative Stress: Harms and Benefits for Human Health. Oxid Med Cell Longev. 2017;2017. doi:10.1155/2017/8416763.

14. Thomas C, Mackey MM, Diaz AA, Cox DP. Hydroxyl radical is produced via the Fenton reaction in submitochondrial particles under oxidative stress: implications for diseases associated with iron accumulation. Redox Rep. 2009;14:102-108.

15. Birben E, Sahiner UM, Sackesen C, Erzurum S, Kalayci O. Oxidative stress and antioxidant defense. World Allergy Organ J. 2012;5:9-19.

16. Peña-Bautista $\mathrm{C}$, Baquero $\mathrm{M}$, Vento $\mathrm{M}$, Cháfer-Pericás $\mathrm{C}$. Free radicals in Alzheimer's disease: Lipid peroxidation biomarkers. Clin Chim Acta. 2019 Apr; 491:85-90.

17. Yavuzer H, Yavuzer S, Cengiz M, Erman H, Doventas A, Balci H, Erdincler DS, Uzun H. Biomarkers of lipid peroxidation related to hypertension in aging. Hypertens Res. 2016;39:342-348.

18. Tsikas D. Assessment of lipid peroxidation by measuring malondialdehyde (MDA) and relatives in biological samples: Analytical and biological challenges. Anal Biochem. 2017;524:13-30.

19. Repetto M, Semprine J, Boveris A. lipid peroxidation: chemical mechanism implications and analytical determination. Intech. 2016;i(tourism):13.

20. Sakai K, Kino S, Masuda A, Takeuchi M, Ochi T, Osredkar J, Rejc B Gersak K, Ramarathnam N, Kato Y. Determination of HEL (Hexanoyllysine adduct): a novel biomarker for omega-6 PUFA oxidation. Subcell Biochem. 2014;77:61-72.

21. Huang CS, Chang LS, Anderson ME, Meister A. Catalytic and regulatory properties of the heavy subunit of rat kidney gamma-glutamylcysteine synthetase. J Biol Chem. 1993;268:19675-19680.

22. DeLeve LD, Kaplowitz N. Glutathione metabolism and its role in hepatotoxicity. Pharmacol Ther. 1991;52:287-305.

23. Kim JS, Kwon WY, Suh GJ, Kim KS, Jung YS, Kim SH, Lee SE. Plasma glutathione reductase activity and prognosis of septic shock. J Surg Res. 2015;200:298-307.

24. Mandal PK, Saharan S, Tripathi M, Murari G. Brain glutathione levels--a novel biomarker for mild cognitive impairment and Alzheimer's disease. Biol Psychiatry. 2015;78:702-710.

25. Teskey G, Abrahem R, Cao R, Gyurjian K, Islamoglu H, Lucero M, Martinez A, Paredes E, Salaiz O, Robinson B, Venketaraman V. Chapter Five - Glutathione as a Marker for Human Disease. 2018;141-159.

26. Cheng Y, Xu T, Li S, Ruan H. GPX1, a biomarker for the diagnosis and prognosis of kidney cancer, promotes the progression of kidney cancer. Aging (Albany NY). 2019;11:12165-12176.

27. Espinoza SE, Guo H, Fedarko N, DeZern A, Fried LP, Xue QL, Leng S, Beamer B, Walston JD. Glutathione peroxidase enzyme activity in aging. J Gerontol A Biol Sci Med Sci. 2008;63:505-509.

28. Li S, Yan T, Yang JQ, Oberley TD, Oberley LW. The role of cellular glutathione peroxidase redox regulation in the suppression of tumor cell growth by manganese superoxide dismutase. Cancer Res. 2000;60:3927-3939.
29. Imai $\mathrm{H}$, Nakagawa $\mathrm{Y}$. Biological significance of phospholipid hydroperoxide glutathione peroxidase (PHGPx, GPx4) in mammalian cells. Free Radic Biol Med. 2003;34:145-169.

30. Liu D, Sun L, Tong J, Chen X, Hui L, Qifan Z. Prognostic significance of glutathione peroxidase 2 in gastric carcinoma. Tumor Biol. 2017:1-9.

31. Fındıklı E, Camkurt MA, İzci F, Karaaslan MF, Fındıklı HA, Sümer $P$, Kurutaş EB. The Diagnostic Value of Malondialdehyde, Superoxide Dismutase and Catalase Activity in Drug Naïve, First Episode, NonSmoker Generalized Anxiety Disorder Patients. Clin Psychopharmacol Neurosci. 2018;16:88-94.

32. Park SY, Nair PMG, Choi J. Characterization and expression of superoxide dismutase genes in Chironomus riparius (Diptera, Chironomidae) larvae as a potential biomarker of ecotoxicity. Comp Biochem Physiol Part C Toxicol Pharmacol. 2012;156:187-194.

33. Fukai T, Ushio-Fukai M. Superoxide dismutases: role in redox signaling, vascular function, and diseases. Antioxid Redox Signal. 2011;15:15831606.

34. García-Medina S, Galar-Martínez M, Gómez-Oliván LM. Lara KR, Flores HI, Gasca-Pérez E. Relationship between genotoxicity and oxidative stress induced by mercury on common carp ( Cyprinus carpio ) tissues Relationship between genotoxicity and oxidative stress induced by mercury on common carp ( Cyprinus carpio ) tissues. Aquat Toxicol. 2018;192:207-215.

35. Regoli F, Giuliani ME, Benedetti M, Arukwe A. Molecular and biochemical biomarkers in environmental monitoring: a comparison of biotransformation and antioxidant defense systems in multiple tissues. Aquat Toxicol. 2011;105(Suppl 3-4):56-66.

36. Teschke R. Alcoholic Liver Disease: Alcohol Metabolism, Cascade of Molecular Mechanisms, Cellular Targets, and Clinical Aspects. Biomedicines. 2018;6:106.

37. Barr DB, Buckley B. In vivo biomarkers and biomonitoring in reproductive and developmental toxicity. Reprod Dev Toxicol. 2011;253-265.

38. McLaughlin LA, Paine MJ, Kemp CA, Maréchal JD, Flanagan JU, Ward CJ, Sutcliffe MJ, Roberts GC, Wolf CR. Why is quinidine an inhibitor of cytochrome P450 2D6? The role of key active-site residues in quinidine binding. J Biol Chem. 2005;280:38617-38624.

39. Mannheimer B, von Bahr C, Pettersson H, Eliasson E. Impact of multiple inhibitors or substrates of cytochrome P450 2D6 on plasma risperidone levels in patients on polypharmacy. Ther Drug Monit. 2008;30:565-569.

40. Lash LH, Hines RN, Gonzalez FJ, Zacharewski TR, Rothstein MA. Genetics and susceptibility to toxic chemicals: do you (or should you) know your genetic profile? J Pharmacol Exp Ther. 2003;305:403-409.

41. Hicks JK, Bishop JR, Sangkuhl K, Müller DJ, Ji Y, Leckband SG, Leeder JS, Graham RL, Chiulli DL, LLerena A, Skaar TC, Scott SA, Stingl JC, Klein TE, Caudle KE, Gaedigk A; Clinical Pharmacogenetics Implementation Consortium. Clinical Pharmacogenetics Implementation Consortium (CPIC) Guideline for CYP2D6 and CYP2C19 Genotypes and Dosing of Selective Serotonin Reuptake Inhibitors. Clin Pharmacol Ther. 2015;98:127-134.

42. van Schaik RHN. 6. Dose Adjustments Based on Pharmacogenetics of CYP450 Enzymes. EJIFCC. 2008;19:42-47.

43. Ames BN, Mccann J, Yamasaki E. Methods for detecting carcinogens and mutagens with the Salmonella/mammalian-microsome mutagenicity test. Mutat Res. 1975;31:347-364. 
44. Maynard S, Fang EF, Croteau MS-KDL, Bohr VA. DNA Damage, DNA Repair, Aging, and Neurodegeneration. Cold Spring Harb Perspect Med. 2015;5:1-18.

45. Clancy S. DNA Damage \& Repair: Mechanisms for Maintaining DNA Integrity. Nature Education. 2008;1:103.

46. Nikitaki Z, Hellweg CE, Georgakilas AG, Ravanat JL. Stress-induced DNA damage biomarkers: Applications and limitations. Front Chem. 2015;3:1-15.

47. Weston A, Harris CC. Carcinogen Metabolism. 2003. Available from: https://www.ncbi.nlm.nih.gov/books/NBK13379/ Accessed May 14, 2020.

48. Hwang ES, Bowen PE. DNA damage, a biomarker of carcinogenesis: its measurement and modulation by diet and environment. Crit Rev Food Sci Nutr. 2007; 47:27-50.

49. Harden A, Young WJ. The Alcoholic Ferment of Yeast-Juice. Proc R Soc B Biol Sci. 1906;77:405-420.

50. Yaku K, Okabe K, Nakagawa T. NAD metabolism: Implications in aging and longevity. Ageing Res Rev. 2018;47:1-17.

51. Sultani G, Samsudeen AF, Osborne B, Turner N. NAD+ : A key metabolic regulator with great therapeutic potential. J Neuroendocrinol. 2017;29.

52. Rajman L, Chwalek K, Sinclair DA. Therapeutic Potential of NADBoosting Molecules: The In Vivo Evidence. Cell Metab. 2018;27:529-547.

53. Ying $W$. NAD $/ N A D H$ and NADP+/NADPH in cellular functions and cell death: regulation and biological consequences. Antioxid Redox Signal. 2008;10:179-206.

54. Katsyuba E, Auwerx J. Modulating NAD+ metabolism, from bench to bedside. EMBO J. 2017;36:2670-2683.

55. Xiao W, Wang RS, Handy DE, Loscalzo J. NAD(H) and NADP(H) Redox Couples and Cellular Energy Metabolism. Antioxid Redox Signal. 2018;28:251-272.

56. Gerner EW, Meyskens FL Jr. Polyamines and cancer: old molecules, new understanding. Nat Rev Cancer. 2004;4:781-792.

57. Gerner EW, Stringer DE. Polyamine pools and cancer prevention. Polyam Cell Signal Polyam Cell Signal. 2006;329-346.

58. Nowotarski SL, Woster PM, Casero RA Jr. Polyamines and cancer: implications for chemotherapy and chemoprevention. Expert Rev Mol Med. 2013 Feb 22;15:e3.

59. Merali S, Barrero CA, Sacktor NC, Haughey NJ, Datta PK, Langford D, Khalili K. Polyamines: Predictive Biomarker for HIV-Associated Neurocognitive Disorders. J AIDS Clin Res. 2014;5:1000312.

60. Vargas AJ, Ashbeck EL, Thomson CA, Gerner EW, Thompson PA. Dietary polyamine intake and polyamines measured in urine. Nutr Cancer. 2014;66:1144-1153.

61. Codoñer-Franch P, Tavárez-Alonso S, Murria-Estal R, Herrera-Martín G, Alonso-Iglesias E. Polyamines are increased in obese children and are related to markers of oxidative/nitrosative stress and angiogenesis. J Clin Endocrinol Metab. 2011;96:2821-2825.

62. Schipper RG, Romijn JC, Cuijpers VM, Verhofstad AA. Polyamines and prostatic cancer. Biochem Soc Trans. 2003;31:375-380.

63. Ahmed SA, Elghandour AH, Elgendy HS. Synthesis of pteridines derivatives from different heterocyclic compounds. Der Pharma Chem. 2014;6:194-219.
64. Chittiboyina S, Chen Z, Chiorean EG, Kamendulis LM, Hocevar BA. The role of the folate pathway in pancreatic cancer risk. PLoS One. 2018;13:e0193298.

65. Crider KS, Yang TP, Berry RJ, Bailey LB. Folate and DNA methylation: a review of molecular mechanisms and the evidence for folate's role. Adv Nutr. 2012;3:21-38.

66. Pieroth R, Paver S, Day S, Lammersfeld C. Folate and Its Impact on Cancer Risk. Curr Nutr Rep. 2018;7:70-84.

67. Walt DR, Rios-Mercadillo VM, Auge J, Whitesides GM. Synthesis of nicotinamide adenine dinucleotide (NAD) from adenosine monophosphate (AMP). J Am Chem Soc. 1980;102:7805-7806.

68. Zhu M, Li B, Ma X, Huang C, Wu R, Zhu W, Li X, Liang Z, Deng F, Zhu J, Xie W, Yang X, Jiang Y, Wang S, Wu J, Geng S, Xie C, Zhong C, Liu H. Folic Acid Protected Neural Cells Against Aluminum-MaltolateInduced Apoptosis by Preventing miR-19 Downregulation. Neurochem Res. 2016;41:2110-2118.

69. Ju J. Beyond Thymidylate Synthase and Dihydrofolate Reductase: Impact of Non-coding microRNAs in Anticancer Chemoresistance. Curr Enzym Inhib. 2012;8:118-123.

70. Vidmar M, Grželj J, Mlinarič-Raščan I, Geršak K, Dolenc MS. Medicines associated with folate-homocysteine-methionine pathway disruption. Arch Toxicol. 2019;93:227-251.

71. Angelo G. High Homocysteine | Linus Pauling Institute | Oregon State University. Oregon State University. Available from: https://lpi. oregonstate.edu/mic/health-disease/high-homocysteine Published 2015. Accessed June 4, 2020.

72. Kim YI, Pogribny IP, Basnakian AG, Miller JW, Selhub J, James SJ, Mason JB. Folate deficiency in rats induces DNA strand breaks and hypomethylation within the $\mathrm{p} 53$ tumor suppressor gene. Am J Clin Nutr. 1997;65:46-52.

73. Hiraoka M, Kagawa Y. Genetic polymorphisms and folate status. Congenit Anom (Kyoto). 2017;57:142-149.

74. Das PM, Singal R. DNA methylation and cancer. J Clin Oncol. 2004;22:4632-4642.

75. Sibani S, Melnyk S, Pogribny IP, Wang W, Hiou-Tim F, Deng L, Trasler J, James SJ, Rozen R. Studies of methionine cycle intermediates (SAM, $\mathrm{SAH}$ ), DNA methylation and the impact of folate deficiency on tumor numbers in Min mice. Carcinogenesis. 2002;23:61-65.

76. Medici V, Halsted CH. Folate, alcohol, and liver disease. Mol Nutr Food Res. 2013;57:596-606.

77. Heidelbaugh JJ. Proton pump inhibitors and risk of vitamin and mineral deficiency: evidence and clinical implications. Ther Adv Drug Saf. 2013;4:125-133.

78. Zhang L, Xue Z, Liu Q, Liu Y, Xi S, Cheng Y, Li J, Yan J, Shen Y, Xiao C, Xie Z, Qiu Z, Jiang H. Disrupted folate metabolism with anesthesia leads to myelination deficits mediated by epigenetic regulation of ERMN. EBioMedicine. 2019;43:473-486.

79. Burton $\mathrm{C}, \mathrm{Ma} \mathrm{Y}$. The role of urinary pteridines as disease biomarkers. Pteridines. 2017;28:1-21. doi:10.1515/pterid-2016-0013.

80. Asci A, Baydar T, Cetinkaya R, Dolgun A, Sahin G. Evaluation of neopterin levels in patients undergoing hemodialysis. Hemodial Int. 2010;14:240-246.

81. Melichar B, Spisarová M, Bartoušková M, Krčmová LK, Javorská L, Študentová H. Neopterin as a biomarker of immune response in cancer patients. Ann Transl Med. 2017;5:280. 
82. Gieseg SP, Baxter-Parker G, Lindsay A. Neopterin, Inflammation, and Oxidative Stress: What Could We Be Missing? Antioxidants (Basel). 2018;7:80.

83. Schennach H, Meyersbach P, Schönitzer D, Fuchs D. Additional neopterin screening to improve safety of blood donations. Pteridines. 2000;11:76-80.

84. Lindsay A, Janmale T, Draper N, Gieseg SP. Measurement of changes in urinary neopterin and total neopterin in body builders using SCX HPLC. 2014;25:53-62.
85. Eisenhut M. Neopterin in Diagnosis and Monitoring of Infectious Diseases. J Biomark. 2013;2013:196432.

86. Kuzkaya N, Weissmann N, Harrison DG, Dikalov S. Interactions of peroxynitrite, tetrahydrobiopterin, ascorbic acid, and thiols: implications for uncoupling endothelial nitric-oxide synthase. J Biol Chem. 2003;278:22546-22554. 